\title{
The jejunoileal bypass provokes morphological changes in the large intestine? An experimental study in rats $^{1}$
}

\author{
A derivação jejuno-ileal provoca alterações morfológicas no intestino grosso? Estudo \\ experimental em ratos
}

\author{
Maria Cristina Costa Resck ${ }^{\mathrm{I}}$, Norair Salviano dos Reis ${ }^{\mathrm{II}}$, Denismar Alves Nogueira ${ }^{\mathrm{III}}$, Marina Rachel Araujo ${ }^{\mathrm{IV}}$, Luiz Roberto \\ Lopesv, Nelson Adami Andreollovi \\ IFellow PhD degree in Surgery, Postgraduate Program in Surgical Sciences, UNICAMP, Assistant Professor, Anatomy Department, Faculty of \\ Veterinary Medicine, UNIFENAS, Alfenas-MG, Brazil. Conception, design, acquisition and interpretation of data; manuscript writing.

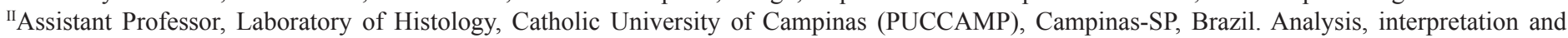 \\ histopathogical examinations.

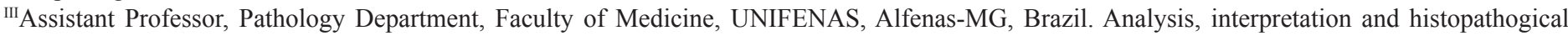 \\ examinations.

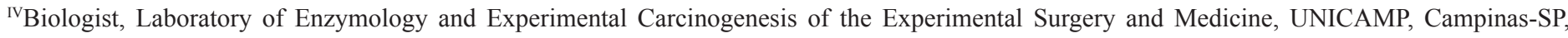 \\ Brazil. Design and acquisition of data. \\ ${ }^{v}$ Associate Professor, Digestive Disease Division, Department of Surgery, Faculty of Medical Sciences, UNICAMP, Campinas-SP, Brazil. Analysis \\ and interpretation of data. \\ ${ }^{\mathrm{VI}}$ Full Professor, Digestive Disease Division, Department of Surgery, Faculty of Medical Sciences, UNICAMP, Campinas-SP, Brazil. Tutor, conception \\ and design.
}

\section{ABSTRACT}

PURPOSE: To analyse histopathological alterations characterized by the mitotic index in the mucosa of the large intestine in Wistar rats submitted to jejunoileal bypass operation after continued administration of sodium nitrite and vitamin $\mathrm{C}$ to different groups.

METHODS: Eighty male Wistar rats were employed and separated into 12 groups. In the control group (20 rats): five animals ingested only water; five animals received vitamin C; five animals received sodium nitrite and five received sodium nitrite + vitamin $\mathrm{C}$. In the sham group (20 rats), the animals were anesthetized and underwent midline laparotomy and only intestinal manipulation was performed: five animals ingested only water; five animals received vitamin C; five animals received sodium nitrite and five received sodium nitrite + vitamin C. In the operated group 40 rats underwent a jejunoileal bypass surgery: ten animals ingested only water; ten animals received vitamin $\mathrm{C}$; ten animals received sodium nitrite and ten received sodium nitrite + vitamin $\mathrm{C}$. The mean weight of the animals was measured weekly. The large intestine was subdivided into cecum $(\mathrm{S} 1)$, ascending colon $\left(\mathrm{S}_{2}\right)$, transverse colon $\left(\mathrm{S}_{3}\right)$, descending colon $\left(\mathrm{S}_{4}\right)$ and rectum $\left(\mathrm{S}_{5}\right)$ for histopathological analysis and mitotic counts. The statistical analysis was used to compare the mitotic indices. The level of significance was $5 \%$.

RESULTS: The mean of all the segments indicates that the sodium nitrite+vitamin $\mathrm{C}$ group obtained the lowest mitotic index compared to the other treatments in the control group. The segments $\mathrm{S}_{1}$ and $\mathrm{S}_{2}$ showed a statistical difference with the vitamin $\mathrm{C}$ treatment: a higher mitotic index and better preservation of the mucosa in the operated group. In the sham group the main statistical difference occurred only in the sodium nitrite+vitamin $\mathrm{C}$ group between the means of the segments.

CONCLUSIONS: The comparison of all the colonic segments of the various groups revealed a lower mitotic index in the animals treated with sodium nitrite+vitamin C. In addition, it was found that vitamin $\mathrm{C}$ did not present a statistically significant inhibiting effect on the preservation of the mucosa and the mitotic index.

Key words: Sodium Nitrite. Jejunoileal Bypass. Intestine, Large. Mitosis. Ascorbic Acid. Rats.

\section{RESUMO}

OBJETIVO: Analisar as alterações histopatológicas caracterizada pelo índice mitótico na mucosa do intestino grosso em ratos Wistar 
submetidos a operação de bypass jejunoileal após a administração continuada de nitrito de sódio e vitamina C para diferentes grupos. MÉTODOS: Oitenta ratos Wistar foram utilizados e separados em 12 grupos. No grupo controle (20 ratos): cinco animais ingeriram apenas água; cinco animais receberam vitamina $\mathrm{C}$, cinco animais receberam nitrito de sódio e cinco receberam nitrito de sódio + vitamina C. No grupo sham (20 ratos), os animais foram anestesiados e submetidos a laparotomia mediana e só a manipulação intestinal foi realizada: cinco animais ingeriram apenas água; cinco animais receberam vitamina $\mathrm{C}$, cinco animais receberam nitrito de sódio e cinco receberam nitrito de sódio + vitamina C. No grupo operado 40 ratos foram submetidos a uma cirurgia de bypass jejunoileal: dez animais ingeridos apenas água; dez animais receberam vitamina $\mathrm{C}$, dez animais receberam nitrito de sódio e dez nitrito de sódio + vitamina C. O peso médio dos animais foi medido semanalmente. O intestino grosso foi subdividido em ceco (S1), cólon ascendente (S2), cólon transverso (S3), cólon descendente (S4) e reto (S5) para análise histopatológica e contagem das mitoses. A análise estatística foi utilizado para comparar os índices mitóticos. O nível de significância foi de $5 \%$.

RESULTADOS: A média de todos os segmentos indica que o grupo que ingeriu nitrito de sódio + vitamina $\mathrm{C}$ obteve o menor índice mitótico em relação aos demais tratamentos no grupo controle. Os segmentos S1 e S2 mostraram uma diferença estatística com a vitamina $\mathrm{C}$ de tratamento: um maior índice mitótico e melhor preservação da mucosa no grupo operado. No grupo sham a principal diferença estatística ocorreu apenas no grupo que ingeriu nitrito de sódio + vitamina $\mathrm{C}$ entre as médias dos segmentos.

CONCLUSÕES: A comparação de todos os segmentos do colon dos vários grupos revelaram um menor índice de mitose nos animais tratados com nitrito de sódio + vitamina C. Além disso, a vitamina C não apresentou efeito inibidor, estatísticamente significativo, na preservação da mucosa e do índice de mitoses.

Descritores: Nitrito de Sódio. Derivação Jejuno-Ileal. Intestino Grosso. Mitose. Ácido Ascórbico. Ratos.

\section{Introduction}

Morbid obesity is currently seen as one of the most worrying public health problems because of its increase and the serious consequences that may result. It is a multifactorial phenomenon that involves genetic, behavioral, psychological, social, metabolic and endocrine components ${ }^{3}$. The control of morbid obesity through surgical procedures results in a mechanism of restriction and / or malabsorption of food intake. According to the Federal Council of Medicine of Brazil, there are three recognized and regulated surgical techniques: vertical gastroplasty, Roux-en-Y gastroplasty (Fobi-Capella procedure) and Roux-en-Y gastroplasty with biliopancreatic diversion (Scopinaro procedure $)^{1-3}$. The jejunoileal bypass is a malabsorptive procedure and singly is no longer recommended to be performed in humans ${ }^{4,5}$.

The reconstruction of the digestive tract after gastroplasties is made with jejuno-jejunal bypass away from the duodenum or jejunoileal bypass and both Roux-en-Y. The malabsorptive procedures cause a significant reduction of intestinal absorption and allow larger amounts of pancreatic secretion and biliary salts, which normally would be absorbed by the small intestine, to reach the large intestine ${ }^{2,6}$. Biliary salts are considered as cofactors in colon carcinogenesis, and another important effect is the induction of cell proliferation, which plays a known role in the carcinogenic phenomenon $^{2,6-9}$.
The bypass jejunoileal causes metabolic changes that can lead to colon cancer development. Three cases of colon cancer were described in the last 20 years, despite the fact that only in United States more than 100.000 patients were submitted to bariatric surgery ${ }^{2}$. Davis et al. ${ }^{9}$ emphatized that patients may die before colon cancer development, reversal of jejunoileal bypass due to associated complications and under reporting of these cases.

Vitamin C, also called ascorbic acid (AA), acting as an antioxidant, is able to capture the free oxygen resulting from cellular metabolism, preventing them from binding with free radicals, phenomenon that cause cellular damage and cancer ${ }^{10-12}$. Many evidences suggest the possible antioxidant effects in the prevention of carcinogenesis based on experimental studies that demonstrate their ability to neutralize and eliminate free radicals. Epidemiological studies show that geographical differences in the incidence of certain tumors may be linked with the consumption of antioxidants, and yet individualized group studies have suggested an inverse relationship between antioxidant intake and cancer risk. Humans and other primates, and guinea pigs, are the only mammals unable to synthesize AA, and recent studies have revealed various functions, besides those already described in the processes of wound healing, maintaining the intracellular integrity, capillary integrity, immune responses, allergic reactions and increased absorption of non-hemic iron ${ }^{11-14}$.

Sodium and potassium nitrite and nitrate salts have been used for centuries as preservatives of all kinds of meats, 
and effectively inhibit the toxicity of Clostridium botulinum. The N-nitroso compounds show a remarkable degree of organic specificity which varies according to their chemical structures. Tumors have been induced in most organs of rodents and other animals by administration of different types of these compounds under very variable experimental conditions ${ }^{11,15}$.

The objectives of this experimental work were to analyse the histopathological changes characterized by the mitotic index in the mucosa of the large intestine of rats submitted to jejunoileal bypass operation, after continued administration of sodium nitrite and vitamin $\mathrm{C}$ in different groups.

\section{Methods}

The experiment was approved by the Ethics Committee for Experimental Animal Surgery, Institute of Biology at UNICAMP (protocol number 1694-1) and performed in the Surgery Unit of the Faculty of Veterinary Medicine, José do Rosário Vellano University, UNIFENAS (surgery and observation of the animals), and in the Laboratory of Enzymology and Experimental Carcinogenesis of the Experimental Surgery and Medicine, UNICAMP (euthanasia of the animals).

Eighty male five-month old Wistar rats (Rattus norvegicus albinus, Rodentia Mammalia), weighing 450-550g, were provided by the CEMIB (Animal Colony) of UNICAMP, where the animals were raised under special conditions, being therefore considered healthy and free from specific diseases (SPF-Specific Pathogen Free). The animals were divided into 12 groups and subgroups of four, each of which housed in polyurethane cages measuring 33 $\mathrm{cm}$ wide, $40 \mathrm{~cm}$ long and $18 \mathrm{~cm}$ high, lined with $5-10 \mathrm{~cm}$ beds of autoclaved and clear sawdust and covered with a lid of metal bars. They were kept at room temperature with a diurnal light cycle and continuous airflow, receiving food and water ad libitum, besides vitamin $\mathrm{C}$ and sodium nitrite for 180 days while remaining in the same cage until the end of the experiment.

In the control group (20 rats), five animals ingested only water; five animals received vitamin $\mathrm{C}$; five animals received sodium nitrite and five received sodium nitrite + vitamin $C$. In the sham group (20 rats), the animals were anesthetized and underwent midline laparotomy and only intestinal manipulation was performed: five animals ingested only water; five animals received vitamin $\mathrm{C}$; five animals received sodium nitrite and five received sodium nitrite + vitamin $\mathrm{C}$. In the operated group (40 rats), ten animals ingested only water; ten animals received vitamin $C$; ten animals received sodium nitrite and ten received sodium nitrite + vitamin $\mathrm{C}$. The animals were anesthetized and underwent midline laparotomy and the intestine was sectioned 3 $\mathrm{cm}$ from the duodenal-jejunal junction, and jejunoileal bypass was performed through a latero-lateral anastomosis in the ileum $2 \mathrm{~cm}$ from the ileocaecal valve (Figure 1). Poligalactina 6-0 surgical sutures were used in a single plane. Ileotomy was made previously to anastomosis, and the segment was sutured and free in the abdominal cavity. After cavity review and cleaning, the abdominal wall was closed using 4-polypropylene continuous suture and then the skin was closed with intradermal sutures with the same type of thread.
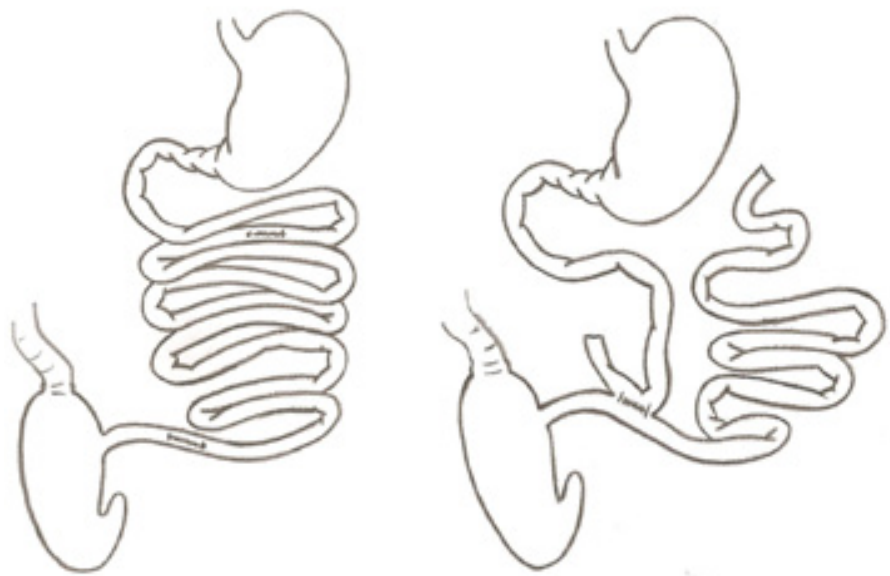

FIGURE 1 - Schematic drawing of the jejunoileal bypass (left) and anastomosis of the proximal jejunum to the ileum $2 \mathrm{~cm}$ from the ileocecal valve (right). Model proposed by Bristol et al. ${ }^{5}$.

The animals were placed in cages with five animals each according to the drug they received. After 180 days, the animals were weighed weekly and for the analysis were divided into segments (S1, S2, S3, S4 and S5) corresponding to the cecum, ascending colon, transverse colon, descending colon and rectum (Figure 2).

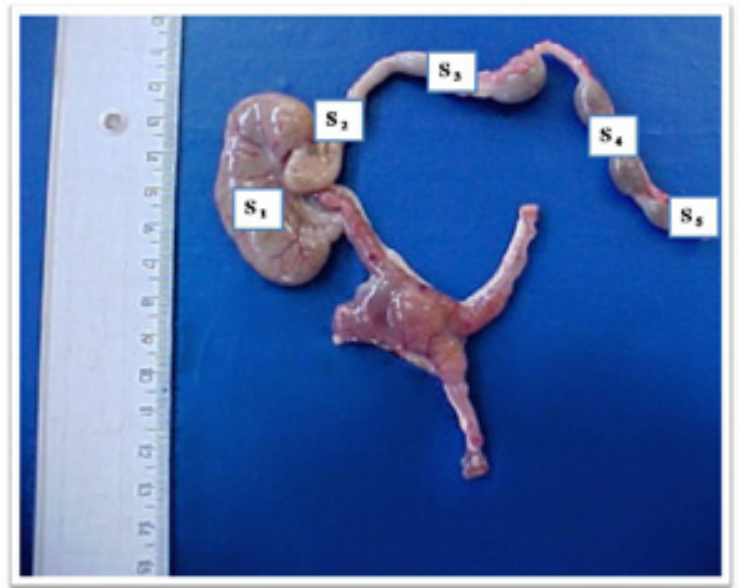

FIGURE 2 - Anatomic segment removed from animal 6 of the operated group showing the segments of the large intestine $\left(\mathrm{S}_{1}, \mathrm{~S}_{2}, \mathrm{~S}_{3}, \mathrm{~S}_{4}\right.$ and $\left.\mathrm{S}_{5}\right)$. 
At the end of the observational period, each animal was weighed again to obtain their final weight and then transported in own cages to the Laboratory of Enzymology and Experimental Carcinogenesis of the Experimental Surgery and Medicine, UNICAMP, Campinas-SP. The animals received an intraperitoneal injection of vincristine sulphate at a dosage of $4 \mathrm{mg} / \mathrm{m}^{2}$ in a single dose for blockade of mitosis and they were then euthanized by deepening of anesthesia, at the same time of the day to avoid diurnal variations in intestinal kinetics. They were then placed in a supine position and their legs were fixed by means of elastics, where laparotomy was performed with the release of the bowel mesentery. The large intestine was prepared by irrigating its lumen with saline to remove fecal pellets and then placed on a cork board in anatomical position in $10 \%$ formalin for 24 hours.

The pieces for histological examination consisted of cross-sectioned segments of the large intestine: cecum (in its middle third), ascending colon (three inches from the junction with the cecum), transverse colon (three inches from the right flexure) descending colon (or three centimeters from the left flexure) and rectum (three inches from the outer margin of the anus).

The specimens were analyzed both internally and externally, histologically processed, and stained by hematoxylineosin (HE). Upon opening the cavity an inventory was made of the anastomosis, the jejunum, colon, liver, and possible formation of tumor masses and diverticula.

All specimens were previously photographed for microscopic analysis and the histopathological studies were performed by two pathologists (N.S.R. - PUCCAMP and D.A.N. UNIFENAS). Mitosis counting was carried out with a Leica Optical Microscope, model DMLB500, with the Leica Qwin program for image capture and analysis. The sections were examined through an oil immersion lens, following the same counting pattern for all slides. It was established that counting must always be from left to right, and from bottom to top, in twenty fields of observation. The Index of Mitosis was considered: the smaller the Index of Mitosis, the greater the destruction of the mucosa, and the higher Index of Mitosis, the greater recovery of the mucosa.

\section{Statistical analysis}

To compare the rate of mitosis, taking into consideration the factors group, treatment segment, the analysis of variance (ANOVA) was used for repeated measures. Due to the wide variability in mitotic rate rank transformation was applied for positions. Multiple comparisons were performed by the Tukey test and contrast profile. To shows the behaviour of the measure in the segments in groups and treatments was employed the graphic presentation with standard deviations. The significance level adopted was $5 \%(\mathrm{p}<0.05)$.

\section{Results}

For comparison of the means, according to the Tukey test (5\%), the sham group showed the highest weight gain, followed by the control group. The operated group showed the lowest weight gain, being negative when compared with the initial weight of the animals.

In the control group, the segments in comparison with treatment and the average of all segments $(p=0.0323)$ indicate that nitrite + vitamin $\mathrm{C}$ had the lowest rate of mitosis when compared with both the nitrite and vitamin $C$ treatments $(p<0.0001)$. There was an interaction between treatments and segments $(p=0.0096)$, where segments S1, S2 and S4 + nitrite treatment with vitamin C were statistically different when compared with both nitrite and vitamin $\mathrm{C}$ treatments. In segments $\mathrm{S} 3$ and S5 all treatments were statistically different (Figure 3). The Figure 4 shows a histological aspect in the segment $\mathrm{S}_{3}$ of the animal 5 in the nitrite+vitamin $\mathrm{C}$ control group.

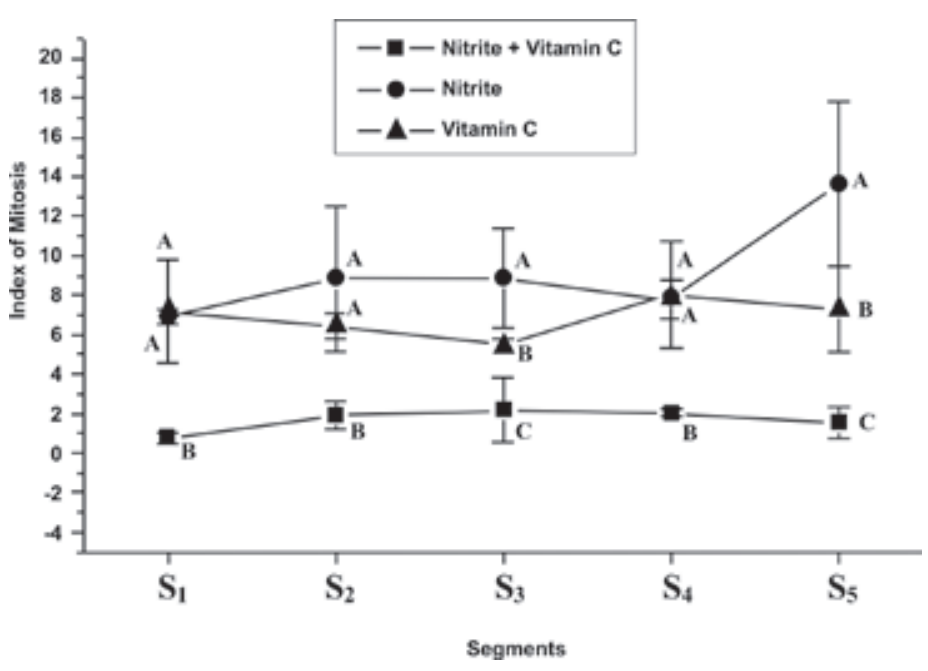

FIGURE 3 - Means and standard deviations of the Index of Mitosis in the segments according to group and treatment. 


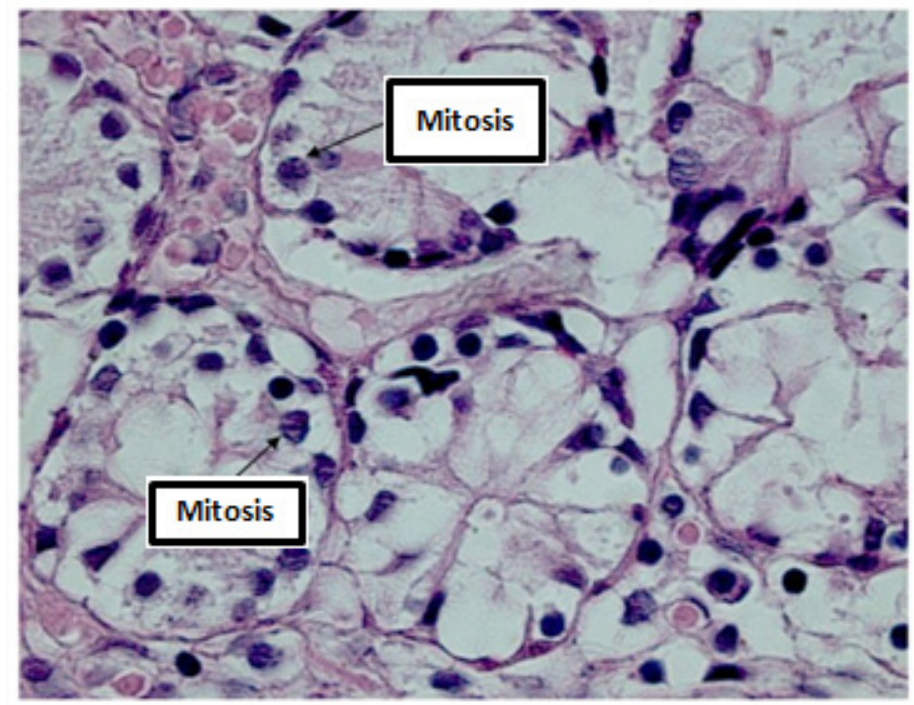

FIGURE 4 - Histological aspect of the animal 5 in the nitrite+vitamin C control group. Mitotic figure in segment $\mathrm{S}_{3}$ (HE 1000x).

In the operated group there was interaction between segment and treatment $(\mathrm{p}<0.0001)$. Comparing the means between treatments $(p=0.0003)$ and between segments $(p<0.0001)$, the segments $\mathrm{S} 1$ and $\mathrm{S} 2$ showed statistical difference in the vitamin $\mathrm{C}$ treatment, which presented a higher rate of mitosis, with consequent better preservation of the mucosa. No statistical difference was found between treatments in the segments S3, S4 and S5 (Figure 5). The Figure 6 shows a histological aspect of a higher number of mitotic figures and tissue preservation in segment $\mathrm{S}_{2}$ of the animal 1 in the vitamin $\mathrm{C}$ operated group.

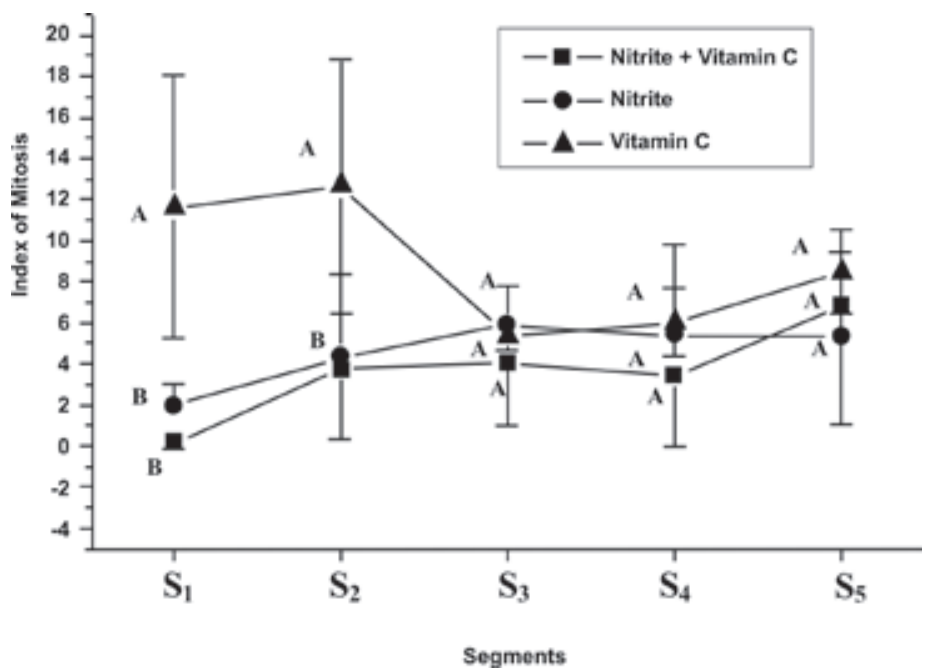

FIGURE 5 - Means and standard deviations of the Index of Mitosis according to group and treatment.

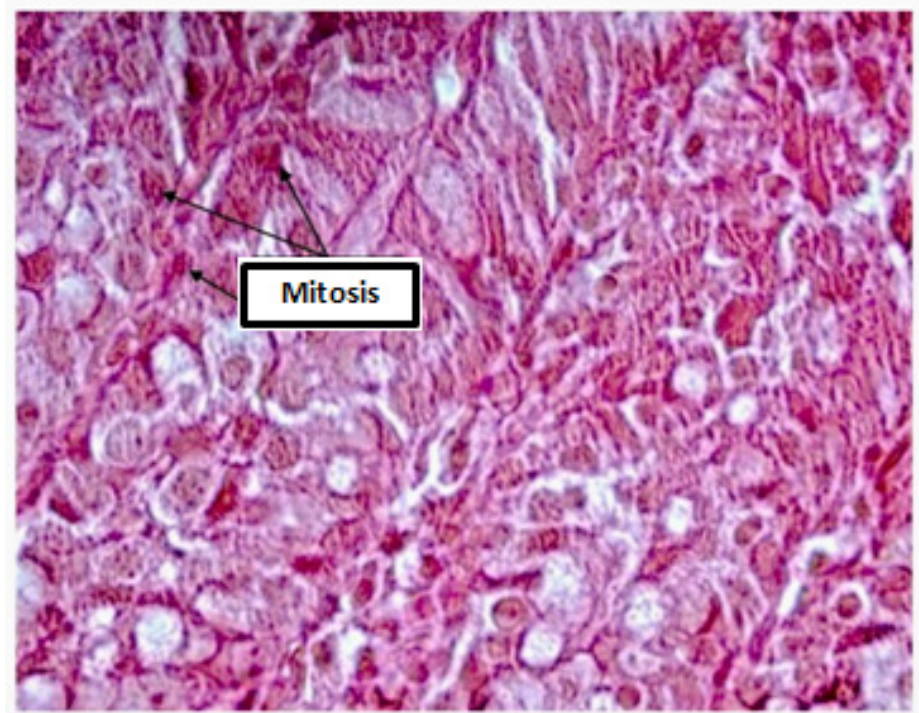

FIGURE 6 - Histological aspect of the animal 1 in the vitamin C operated group, showing a higher number of mitotic figures and tissue preservation in segment $\mathrm{S}_{2}$ (HE 1000x).

In the sham group there was difference only between treatments $(p<0.0001)$, but not between segments $(p=0.0849)$ and neither interaction between segment and treatment $(\mathrm{p}=0.7135)$. The main statistic difference was only in the nitrite+vitamin $\mathrm{C}$ treatment, between the means of the segments, but not between the segments, i.e., the treatments were equivalent between the segments (Figure 7). The Figure 8 shows a histological aspect of mitotic figures in segment $\mathbf{S}_{1}$ of the animal 2 in the nitrite sham group.

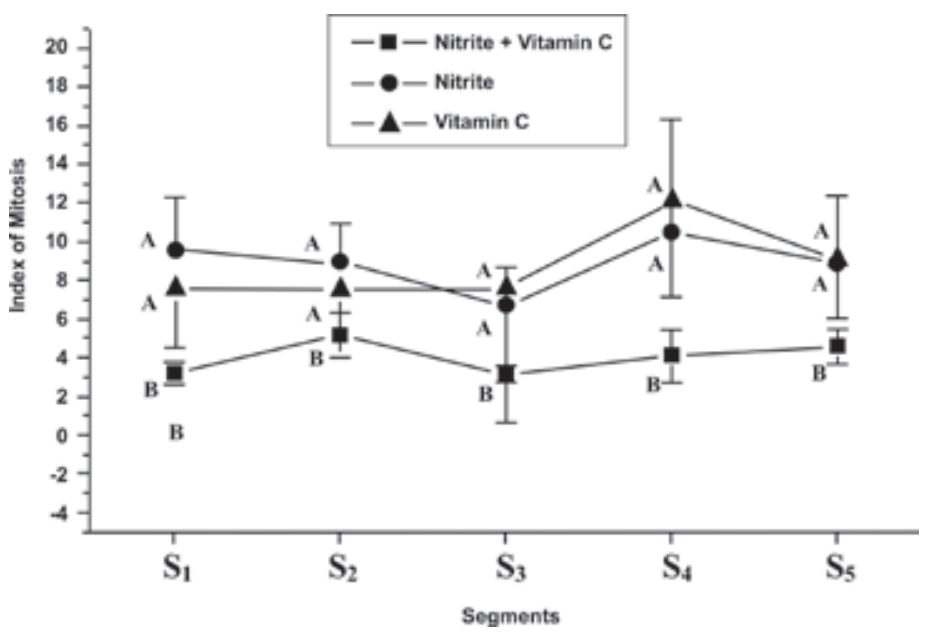

FIGURE 7 - Means and standard deviations of the Index of Mitosis in the segments according to group and treatment. 


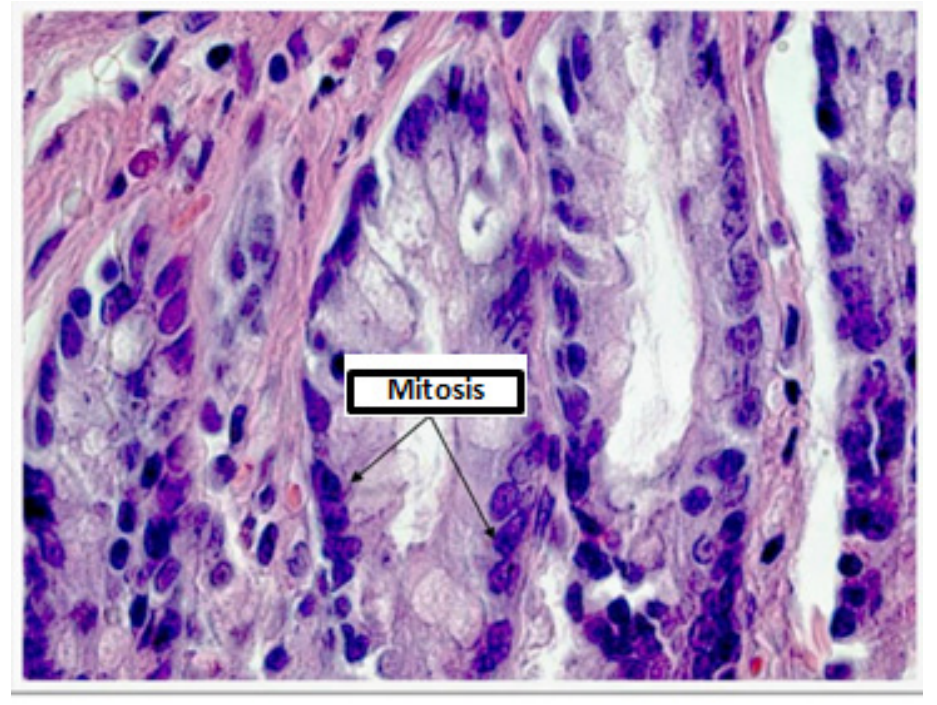

FIGURE 8 - Histological aspect of the animal 2 in the nitrite sham group showing mitotic figures in segment $\mathrm{S}_{1}$ (HE 1000x).

\section{Discussion}

Obesity is currently one of the most serious public health problems. Most of the operations currently performed to treat obesity have some malabsorptive component ${ }^{5}$. The jejunoileal bypass is a malabsorptive surgery and has been used and evaluated in humans ${ }^{2,3}$. However, it is not currently used to treat morbid obesity, serving only as a model for experimental studies aimed at evaluating the metabolic and histopathological changes resulting from intestinal bypass around the gastroduodenal contents ${ }^{17}$.

Patients submitted to jejunoileal bypass had been studied employing colonoscopy, to detect colorectal carcinomas. McFarland et al. ${ }^{18}$ performed colonic biopsies on 38 patients, $10-13$ years after jejunoileal bypass. They found no significant dysplasia or premalignant changes in 371 biopsies. Only one patient presented two tubulovillous adenomata. Sylvan et al. ${ }^{6}$ examined by colonoscopy performing multiple biopsies systematically taken for histopathological studies and flow cytometric DNA analysis a total of thirty women operated on with jejunoileal bypass 11 to 17 years earlier. In only one patient, low-grade dysplasia was detected in an initial adenomatous lesion not visible macroscopically, and no DNA aneuploidy was found. The authors concluded that carcinogenesis is a long process and further surveillance will be demanded before an increased risk for colorectal carcinoma can be excluded. Davis et al. ${ }^{9}$, reported an adenocarcinoma of ileocecal valve after 35 years after jejunoileal bypass and reviewing the literature found two other cases related with this procedure. They concluded that clinical studies may have failed to demonstrate an increased risk for colorectal cancer in bypassed patients.
Some studies have used the rat as an animal model for this procedure ${ }^{4,5,17,19-21}$. Bristol et al. ${ }^{5}$ submitted to Sprague-Dawley rats a jejunoileal derivation of $85 \%$, and analysed the crypt depth in colonic mucosa, after a carcinogen 1,2-dimethylhydrazine (a precursor of azoxymethane) for 6 weeks. The study revealed that in the middle third of the colon the crypts were 33\% deeper after derivation and in the distal third the crypts were $25 \%$ deeper. The crypt cell number doubled in the middle third of the large intestine and tripled in the distal third after derivation, Regarding the adaptation of the large intestine, the animals which underwent bypass had a $17 \%$ increase in size and $29 \%$ in weight, plus a massive increase of $86 \%$ of the cecum. The authors concluded that the data demonstrate substantial and sustained increase in the rates of cell proliferation and adaptation of the large intestine after jejunoileal bypass

Others well conducted experimental studies showed hypertrophy of the villi and mucosa of the loops in active circuit and atrophy of the handles, which revealed a marked bacterial proliferation ${ }^{4,5,21,22}$. Teixeira et al. ${ }^{17}$, after morphometric study of the intestinal mucosa of rats sacrificed 10 weeks after the shunt, noted that the animals had significantly lower weight in the first week, which was recovered on the $14^{\text {th }}$ day and maintained until the end of the study. The volume of the colonic crypts of the three segments of the cecum, right colon, and left colon did not significantly differ between the groups. Tamames et al. ${ }^{21}$ studied the compensatory reaction of the ascending colon after jejunoileal bypass in 115 Wistar rats, and, since the early days, observed a small increase in the intestinal wall of the large intestine in relation to the small intestine, a significant increase in the muscular wall and mucosa. No statistically significant differences were observed in the rate of cryptal cell mitosis. All the studies at the intestinal level showed an increased mitotic index, which, together with the ultrastructural data showing a greater number of cells undergoing necrobiosis, seems to be a major cell renewal ${ }^{19,20}$.

Since the effects of prolonged malabsorption in the large intestine is not well defined, this study aimed to analyse the changes of colonic the mucosa at examining the histopathological changes characterized by the index of mitosis in the large intestine after jejunoileal bypass, and to study the influence of vitamin $C$, sodium nitrite, and sodium nitrite + vitamin $\mathrm{C}$ for a long time at doses that are used as therapeutic and as food preservatives.

The vincristine sulfate was employed in low dosage ( $4 \mathrm{mg}$ / $\mathrm{m}^{2}$ ), applied intraperitoneally, before removal of colonic segments for histopathologic analysis. The vincristine sulphate is a class of antitumor drug employed in cancer treatment, namely Vinca alkaloids, which mechanism of action in low dosage is suppress 
the dynamics of microtubule without appreciably changing the mass of microtubules in the cell, and blockage of the mitosis at the metaphase/anaphase transition. Therefore, the histopathogical studies analysed the number of mitosis found, and the method is safe, meaning if the mucosa is altered or destroyed, the number of mitoses found is low, or conversely, when the mucosa is intact the number of mitoses is high ${ }^{16}$.

Vitamin C, also known as ascorbic acid, is one of 13 key vitamins that are part of a complex group of chemicals essential for the proper functioning of the organs and systems. It is one of water soluble vitamins, which means that the body uses what it needs and eliminates the excess. It is found in foods like citrus fruits, tomatoes, strawberries, sweet pepper and broccoli. The recommended dosage for most people aged over 15 years is $60 \mathrm{mg} /$ day. Among people who need more vitamin $\mathrm{C}$ are pregnant women (70mg), breast feeding women (90-95mg) and smokers (at least $100 \mathrm{mg}$ ). Since vitamin C cannot be stored in the body, it is important to replace it, taking the daily recommended quantity ${ }^{11,13,23,24}$.

Kessler et $a l .{ }^{14}$ studied the ability of vitamin $\mathrm{C}$ to inhibit tumor formation in the liver, using DEN at a dose of $6.4 \mathrm{mg} / \mathrm{kg} /$ day, and vitamin $\mathrm{C}$ in doses of $43 \mathrm{mg} / \mathrm{animal} / \mathrm{dia}$ for 135 days in rats and observed that the DEN-treated group showed the formation of carcinoma of the liver in $89.7 \%$ of cases; in the group alternately treated with DEN and vitamin C occurred the formation of liver tumors in $67 \%$ of animals, and the group that received DEN and vitamin $\mathrm{C}$ together, there was formation of tumors in $55.2 \%$ of cases.

Mokhtar et al. ${ }^{15}$ studied the protective effect of vitamin $\mathrm{C}$ and soybeans on carcinogenesis induced by two nitrosated compounds in mice, the dibutylamine (DBA) and sodium nitrite (NS). After 12 months of observation, they demonstrated the onset of hepatoma in $27 \%$ of animals and bladder papilloma in $40 \%$ in groups receiving DBA + NS. The groups who took these drugs together with ascorbic acid and soy did not develop any tumor.

Ramos et al. ${ }^{24}$ studied the inhibitory effect of vitamin $\mathrm{C}$ in esophageal carcinogenesis induced by diethylnitrosamine (DEN) in rats and found that vitamin $\mathrm{C}$ showed a statistically significant inhibitory effect against the occurrence of esophageal tumors experimentally induced by DEN when these drugs were administered jointly.

Scientists have recently made discoveries that lead them to believe that many diseases begin at the cell level, due to a process known as cellular oxidation. It is this process that damages the cell, causing changes in DNA. The cellular oxidation is caused by millions of molecules of the body called free radicals. Sodium nitrite $\left(\mathrm{NaNO}_{2}\right)$ is used as a color fixative and preservative in meats and fish. When pure, it is a white slightly yellowish crystalline powder. It is hygroscopic and very soluble in water. It is slowly oxidized to sodium nitrate $\left(\mathrm{NaNO}_{3}\right)$ by oxygen in the air, which makes it yellow through the release of nitrogen dioxide (NO2). The compound is a strong reducing agent. In the United States of America it can be used only as a mixture with salt (sodium chloride) containing a maximum of $0.6 \%$ sodium nitrite ${ }^{11,15,25,26}$.

Recent studies have found a link between high processed meat consumption and colon cancer, possibly due to preservatives such as sodium nitrite ${ }^{26}$, which motivated this research to study the administration over a long period (180 days) of sodium nitrite to rats submitted to jejunoileal bypass analysing possible morphological changes of the large intestine.

The nitrate ion that occurs naturally in many products, including vegetables, particularly affecting children and ruminants, can turn into nitrite, especially by bacterial action. Because of these problems these two ions cannot exceed preset limits. Thus, the World Health Organization temporarily establishes the limits of $500 \mathrm{mg} / \mathrm{Kg}$ for nitrate in cured and canned meats, and $200 \mathrm{mg} /$ $\mathrm{kg}$ in cheeses, and $200 \mathrm{mg}$ of nitrite in cured and canned meats. For drinking water the maximum allowed is $50 \mathrm{mg} / \mathrm{L}$ for nitrate and $0.1 \mathrm{mg} / \mathrm{L}$ for nitrite content. However, the recommended value for nitrate levels in water consumed by pregnant women and infants should not exceed $10 \mathrm{mg} / \mathrm{L}$. In our study the concentration of nitrite was based on the World Health Organization and the Ministry of Health, who allow a maximum of $200 \mathrm{rpm}$, and its dilution in water is not affected by the presence of chlorine, being rapidly oxidized by $\mathrm{it}^{18}$.

During the observation period of 180 days in this research it was observed that the non-operated animals presented higher weight gain, and that there was an interaction between groups, treatment and segment with variations in the rates of mitosis. The operated group showed the lowest weight gain, being negative when compared with the initial weight of the animals.

The literature review shows that the adaptive response of the large intestine follows similar macroscopic, microscopic and ultrastructural parameters as described in the residual intestine $e^{4,17-20}$ Nevertheless, the differences observed in our experimental study can be described by counting the mitotic index of the large intestine after injection of vincristine sulfate in all animals of control, sham and operated groups, and subsequent correlation of the number of mitoses with the mucosal cell capacity of the segment.

Comparing the segments with treatments, in the control group, the animals that received nitrite + vitamin $\mathrm{C}$ had the lowest rate of mitosis when compared with both the nitrite and vitamin 
C treatments $(p<0.05)$. Therefore, it was observed an interaction between treatments and segments $(p<0.05)$. In the operated group, there was a statistically significant interaction between segment and treatment $(p<0.05)$. Comparing the means between treatments and between segments the segments $\mathrm{S} 1$ and $\mathrm{S} 2$ showed statistical difference in the vitamin $C$ treatment $(\mathrm{p}<0.05)$, which presented a higher rate of mitosis, with consequent better preservation of the mucosa. No statistical difference was found between treatments in the segments S3, S4 and S5.

Therefore, the results of this study showed that vitamin $\mathrm{C}$ associated with sodium nitrite had no inhibitory effect on tissue injury and neither on the mitotic index.

The colorectal cancer is the second leading cause of cancer death in western countries and one of the most frequently diagnosed malignancies in the United States according to the National Cancer Institute ${ }^{26,27}$. Epidemiologically, the studies in animal models suggest increased risk of colon cancer after jejunoileal derivations due to increased inhibition of apoptosis, and crypt cell hyperproliferation resulting in crypt hyperplasia. These findings may directly influence the contemporary surgical practice ${ }^{4,9,22}$. Considering the colonic hyperplasia resulting from this procedure, a large number of young and middle-aged patients may be at risk of developing colorectal cancer.

Concluding, further studies should be done after the jejunoileal bypass, but with greater attention to patients, in an attempt to reduce comorbidities, and with awareness regarding eating habits that favor the use of food with preservatives.

\section{Conclusions}

Comparing all colonic segments evaluated in the various groups, it was observed that animals given sodium nitrite plus vitamin $\mathrm{C}$ had fewer mitoses. Moreover, it was found that vitamin $\mathrm{C}$ showed no statistically significant inhibitory effect on the preservation of the mucosa and the index of mitosis.

\section{References}

1. Joia-Neto L, Lopes-Junior AG, Jacob CE. Digestive and metabolic changes in postoperative bariatric surgery. ABCD Arq Bras Cir Dig. 2010;23(4):266-9.

2. Nassif PAN, Lopes AD, Lopes GL, Martins PR, Pedri LE, Varaschim M, Bopp DS. Changes in the pre- and postoperative parameters in metabolic syndrome patients submitted to Roux-en-Y gastric bypass. ABCD Arq Bras Cir Dig. 2009;22(3):165-70.

3. Lemmens VE, Oenema A, Klepp KI, Henriksen JHB, Brug J. A systematic review of the evidence regarding efficancy of obesity preventions among adults. Obes Rev. 2008;9(5):446-5.

4. Chaib SA, Faria RM, Chaib E, Mion Jr D, Laudanna AA.
Histopathological changes in the ileum and jejunum of patients subjected to a bypass operation for treatment of obesity. Rev Hosp Clin Fac Med Sao Paulo. 1983;38(6):231-6.

5. Bristol JB, Wells M, Williamson RCN. Adaptation to jejunoileal bypass promotes experimental colorectal carcinogenesis. Br J Surg. 1984;71(2):123-6.

6. Sylvan A, Sjölund B, Janunger KG, Rutegard J, Steling R, Roos G. Colorectal cancer risk after jejunoileal bypass: dysplasia and DNA content in longtime follow up of patients operated on for morbid obesity. Dis Colon Rectum. 1992;35(3):245-8.

7. Kozoni V, Tsioulias G, Shiff S, Rigas B. The effect of litocholic acid on proliferation and apoptosis in the presence of a colon carcinogen. Carcinogenesis. 2002;21(5):999-1005.

8. Scudamore CH, Freeman HJ. Effects of small bowel transaction, resection, or bypass in 1,2 dimetilhidrazine induced rat intestinal neoplasia. Gastroenterology. 1983;84(4):725-31.

9. Davis K, Markov M, Jasiurkowski B, Ravi J, Patel P, Levater R, Nadir A, Rodriguez J, Van Thiel DH. Adenocarcinoma of the ileocecal valve occurring 35 years after jejunoileal bypass. South Med J. 2008;101(7):772-3.

10. Petroianu A, Alberti LR. Effect of oral suplementation of vitamin $\mathrm{C}$ on intestinal anastomotic resistance. Rev Col Bras Cir. 2011;38(1):54-8 .

11. Kuroiwa $\mathrm{Y}, \underline{\text { Yamada } \mathrm{M}}$, Matsui $\mathrm{K}$, Okamura $\mathrm{T}$, Ishii $\mathrm{Y}$, Masumura $\underline{\mathrm{K}}$, Tasaki M, Umemura T, Mitsumori $\mathrm{K}$, Nohmi $\mathrm{T}$, Hirose $\mathrm{M}$, Nishikawa A. Combined ascorbic acid and sodium nitrite treatment induces oxidative DNA damage-associated mutagenicity in vitro, but lacks initiation activity in rat forestomach epithelium. Toxicol Sci. 2008;104(2):274-82.

12. Del-Rio JV, Beck DE, Opelka FG. Chronic perioperative steroids and colonic anastomotic healing in rats. J Surg Res. 1996;66:13842.

13. Tylor TV, Rimmer S, Day B, Butccher J, Dymock IW. Ascorbic acid supplementation in the treatment of pressure-sores. Lancet. 1974;2:544-6.

14. Kessler H, Husemann B, Wagner W. Potential protective effect of vitamin $\mathrm{C}$ on carcinogenesis caused by nitrosamine in drinking water: an experimental study on Wistar rats. Eur J Surg Oncol. 1992;18:275-81.

15. Mokhtar NM, el-Aaser AA, el-Bolkainy MN, Ibrahim HA, Badr ElDin NK, Moharram NZ. Effect of soybean feeding on experimental carcinogenesis - III carcinogecity of nitrite and dibutylamine in mice: a histopathological study. Eur J Cancer Clin Oncol. 1988;24(3):403-11.

16. Jordan MA. Mechanism of action of antitumor drugs that interact with microtubules and tubulin. Curr Med Chem Anticancer Agents. 2002;2(1):1-17.

17. Teixeira HM, Ribas-Filho, JM Nassif, PAN, Dietz UA, Henriques GS, Aoki S, Pizzol FD. Morphometric analysis of the large intestine mucosa after jejunal ileal bypass in rats. ABCD Arq Bras Cir Dig. 2006;19(4):140-5.

18. Mcfarland R J, Talbot RW, Woolf N, Gazet JC. Dysplasia of the colon after jejunoileal bypass. Br J Surg. 1987;74(1):21-2.

19. Martinez Diez M, Ingelmo A, castiella T, Aguilella V, Martinéz F González. Weight morphometric and morphodynamic intestinal changes after different types of experimental intestinal by-passes. Rev_Esp Enferm Apar Dig. 1983;63(4):305-16.

20. Martinez Diez M, Aguilella V, Cartiella T, Ingelmo A, Ortega J, Martinez F y González M. Experimental evaluation of the importance of food reflux to the excluded intestine as a cause of the failure of the simple model of anti-obesity termino-lateral jejuno-ileal bypass. A weight-change, macroscopic, microscopic and ultrastructural study. Rev_Esp_Enferm Apar Dig. 1984;65(1):15-27. 
21. Tamames Jr S, De Veja DS, Furio V, Tamames S. Compensatory reaction of the ascending colon following jejuno-ileal bypass. Experimental study. Rev Esp Enferm Dig. 1990;78(1):14-22.

22. De Vogel J, van-Eck WB, SesinkAL, Janker-Termont DS, Kleibeuker $J$, van der Meer R. Dietary heme injures surface epithelium resulting in hiperproliferation, inhibition of apoptosis and crypt hyperplasia in rat colon. Carcinogenesis. 2008;29(2):398-403.

23. Goodman M, Bostick RM, Kucuk O, Jones DP. Clinical trials of antioxidants as cancer prevention agents: past, present and future. Free Radic Biol Med. 2011;51(5):1068-84.

24. Schectman G. Estimating ascorbic acid requeriments for cigarette smokers. Ann N Y Acad Sci. 1993;686:335-45.

25. Ramos AC, Araujo MR, Lopes LR, Andreollo NA. Role of the vitamin $\mathrm{C}$ in diethylnitrosamine-induced esophageal cancer in Wistar rats. Acta Cir Bras. 2009;24(3):183-8.

26. Larsson SC, Wolk, A. Meat consumption and risk of colorectal cancer: a meta-analysis of prospective studies. Int $\mathrm{J}$ Cancer. 2006;119(11):2657-64.

27. National Cancer Institute. Institute: surveillance epidemiology and end results. Available from http://seer.cancer.gov/statfacts/html/ colorect.html\#incidence-mortality.

\section{Correspondence:}

Nelson Adami Andreollo

Departamento de Cirurgia-UNICAMP

Rua Alexander Fleming, 181

13083-970 Campinas - SP Brasil

Tel.: (55 19)3521-9448

nandreollo@hotmail.com

Received: January 10, 2012

Review: March 12, 2012

Accepted: April 16, 2012

Conflict of interest: none

Financial source: none

${ }^{1}$ Research performed at Faculty of Veterinary Medicine, Alfenas University (UNIFENAS), Alfenas-MG and Laboratory of Enzymology and Experimental Carcinogenesis of the Experimental Surgery and Medicine Division, Faculty of Medical Sciences, Campinas University (UNICAMP), Campinas-SP, Brazil. Part of PhD thesis, Postgraduate Program in Surgical Sciences, UNICAMP. Tutor: Nelson Adami Andreollo. 